\title{
Analysis Of Hofstede's 5-D Model: The Implications Of Conducting Business In Saudi Arabia
}

\author{
Macgorine A. Cassell, Fairmont State University, USA \\ Rebecca J. Blake, 3L, West Virginia University College of Law, USA
}

\begin{abstract}
This paper analyzes the business and legal environment of Saudi Arabia using Hofstede's five dimensions: power distance, individualism vs. collectivism, masculinity vs. femininity, uncertainty avoidance, and short-term orientation vs. long-term orientation. The purpose of this paper is to provide a comparative analysis of several key traits of the culture in the United States and Saudi Arabia, examine various concepts in Saudi Arabia's business environment that are illustrative of its ranking, and demonstrate the continued viability of Hofstede's model as a stepping-stone to appreciation of culture.
\end{abstract}

Keywords: Culture; Hofstede; United States; Saudi Arabia

\section{INTRODUCTION}

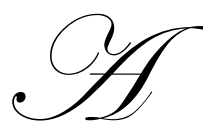

ccording to the Doing Business 2011 Report, the United States and Saudi Arabia rank $5^{\text {th }}$ and $11^{\text {th }}$ respectively for ease of doing business out of the 183 economies analyzed (The International Bank for Reconstruction and Development \& The World Bank, 2011a). Saudi Arabia has made 13 positive reforms for business since 2008 with respect to dealing with construction permits, getting credit, trading across borders, closing businesses, starting businesses, registering property, and protecting investors (The International Bank for Reconstruction and Development \& The World Bank, 2011b). Starting a limited liability company in Saudi Arabia now requires four procedures, five days, and costs 7\% GNI per capita (The International Bank for Reconstruction and Development \& The World Bank, 2011c). However, enforcement of contracts is still problematic with Saudi Arabia ranking 140 out of the 183 economies analyzed for ease of enforcing contracts (The International Bank for Reconstruction and Development \& The World Bank, 2011c).

Studies have indicated that Saudi Arabia has a "fairly homogeneous" culture (Idris, 2007). Saudi Arabia's culture has business and legal implications because the Muslim faith infiltrates all decisions and significantly impacts businesses (Idris, 2007). An understanding and appreciation of the culture in Saudi Arabia is imperative to penetrating and thriving in the business and legal environment. The article "The Clarke Program in East Asian Law and Culture: Exciting Conversations on Law and Culture" in the Spring/Summer edition of the Cornell Law Forum acknowledged the degree in which culture is interwoven with the law stating

to traditionalists who may be surprised to see the study of law linked with culture, Professor Riles responds, cheerily but firmly: "you can't understand the meaning of a legal contract without understanding the culture-religion, kinship, markets"-from which it arose. "A clause in a piece of legislation in, say, Japan may have symbolic value and never be litigated, but if you don't know something about the culture you won't know that" (Myers, 2007, p. $11)$.

One approach to understanding culture is to review managing cross-cultural literature prior to engaging in any international business venture. Dr. Geert Hofstede's model serves as a cultural guide to understanding intercultural differences and synergies by considering the five cultural dimensions of power distance, individualism 
vs. collectivism, masculinity vs. femininity, uncertainty avoidance, and short-term orientation vs. long-term orientation. Dr. Hofstede did not analyze Saudi Arabia individually. Therefore, the score Dr. Hofstede attributed overall to Arab countries is used as the norm for this analysis. This paper analyzes the business and legal environment of Saudi Arabia using Hofstede's five dimensions: power distance, individualism vs. collectivism, masculinity vs. femininity, uncertainty avoidance, and short-term orientation vs. long-term orientation. The purpose of this paper is to provide a comparative analysis of several key traits of the culture in the United States and Saudi Arabia, examine various concepts in Saudi Arabia's business environment that are illustrative of its ranking, and demonstrate the continued viability of Hofstede's model as a stepping-stone to appreciation of culture.

\section{THE POLITICAL, LEGAL, AND ECONOMIC FRAMEWORK}

The Kingdom of Saudi Arabia (Saudi Arabia) is a monarchy located in the Middle East (Central Intelligence Agency, 2011). Saudi Arabia's government consists of the executive, legislative, and judicial branches (U.S. Department of State, 2010). The executive branch is headed by the King and Prime Minister (a member of the Al Saud family) serving as both the chief of state and the head of government under the title Custodian of the Two Holy Mosques (CIA, 2011). The executive cabinet is called the Council of Ministers and members (many being royal family) are appointed by the monarch every four years (CIA, 2011). The legislative branch comprises of the Consultative Council or Majlis al-Shura which consists of a chairman and 150 members that to date have been appointed by the monarch to serve for four year terms (CIA, 2011). The judicial branch comprises of the Supreme Court, the Supreme Judicial Council and the Islamic Courts of First Instance and Appeals (DOS, 2010). Of particular importance to entering business contracts is the fact that special committees handle commercial disputes, although the Supreme Judicial Council decided in early March 2010 to open commercial courts in major cities (CIA, 2011; Fakkar, 2010). To date, Saudi Arabia has not accepted ICJ jurisdiction (CIA, 2011).

There are essentially two legal systems in Saudi Arabia: "[o]ne is based on Shari'ah Islami'iah (Islamic teachings) and the other is based on secularized (non-religious) laws, known as nizam" (Kwong \& Levitt, 2009). In 1992, the Basic Law was adopted declaring that "Saudi Arabia is a monarchy ruled by the sons and grandsons of King Abd Al Aziz Al Saud, and that the Holy Qur'an is the constitution of the country, which is governed on the basis of Islamic law (Shari'a)" (DOS, 2010).

In 2010, Saudi Arabia's GDP was estimated to be $\$ 622.5$ billion, making it $23^{\text {rd }}$ in the world (CIA, 2011). The government has instituted six "economic cities" in the country to encourage economic development (CIA, 2011). The exchange rate in 2010 was "Saudi riyals (SAR) per US dollar - 3.75" (CIA, 2011). Saudi Arabia "holds more than $20 \%$ of the world's proven oil reserves" and oil accounts for "roughly $80 \%$ of budget revenues, $45 \%$ of GDP, and 90\% of export earnings" (CIA, 2011). Figure 1 illustrates Saudi Arabia's main trading partners and products.

Figure 1: Saudi Arabia's Trading Partners

\begin{tabular}{|c|c|}
\hline Exports & Imports \\
\hline Petroleum and Petroleum Products & Machinery, Equipment, Food, Chemicals, Vehicles, Textiles \\
\hline Japan & United States \\
\hline South Korea & China \\
\hline United States & Germany \\
\hline China & Japan \\
\hline India & South Korea \\
\hline Taiwan & India \\
\hline Singapore & United Kingdom \\
\hline & France \\
\hline
\end{tabular}

(CIA, 2011).

\section{THE BUSINESS ENVIRONMENT}

Respect of the culture in Saudi Arabia is imperative prior to business dealings. This is true when considering entering and terminating business contracts to avoiding unwanted contacts with the religious police. An 
important aspect of the business environment revolves around the accommodation of prayer times, days of rest, and fasting. A culture comparison tool by Itim International, an international consulting firm, provides the following snapshot comparison of Hofstede's dimensions for the United States and the Arab World.

Figure 2: Hofstede's Dimensions

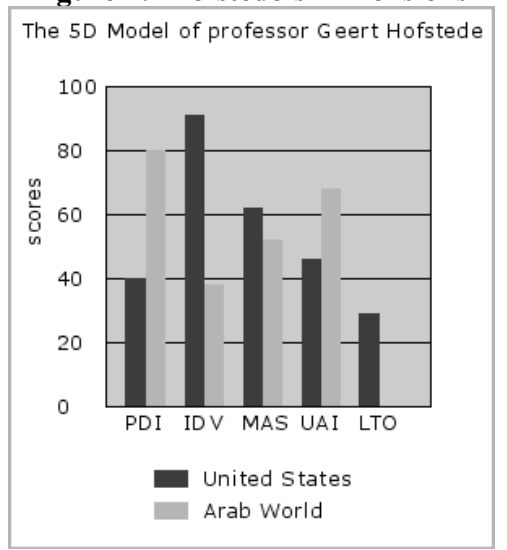

(Itim International (n.d.).

This section provides a comparative analysis of several key traits of the culture in the United States and Saudi Arabia based upon their respective ranking followed by a discussion of various concepts in Saudi Arabia's business environment that are illustrative of its ranking.

\section{Power Distance}

"Power distance is the extent to which the less powerful members of organizations and institutions (like the family) accept and expect that power is distributed unequally" (Hofstede, n.d.). Saudi Arabia's power distance ranking of 80 is "indicative of a high level of inequality of power and wealth within the society. [This ranking suggests that the population has] an expectation and acceptance that leaders will separate themselves from the group and this condition is not necessarily subverted upon the population, but rather accepted by the society as their cultural heritage" (Itim International, n.d.).

Figure 3: Power Distance - United States vs. Saudi Arabia

\begin{tabular}{|l|l|}
\hline \multicolumn{1}{|c|}{ Saudi Arabia (80) } & \multicolumn{1}{c|}{ United States (40) } \\
\hline Inequality is Acceptable & Inequality is Minimized \\
\hline $\begin{array}{l}\text { Rigid/Authoritative Structure } \\
\text { Vertical Hierarchies }\end{array}$ & $\begin{array}{l}\text { Flexible Structures Dominate } \\
\text { "Flatter Organizations" }\end{array}$ \\
\hline Centralized Decision Making & Collective Decision Making \\
\hline Respect for Authority & Respect for Individuality \\
\hline "Large Gaps in Compensation, Authority and Respect" & Authority and Respect is Minimized \\
\hline Fear boss & Challenge Boss \\
\hline Individuals in Power are Privileged & "Supervisors and Employees are Considered Almost as Equals" \\
\hline
\end{tabular}

(Butler, P. n.d.; Itim International, n.d.; Mind Tools, n.d.; Roberts \& Taylor, n.d.).

"Large gaps in compensation, authority, and respect" are characteristic for countries with higher power distance rankings (Mind Tools, n.d). The high power distance in Saudi Arabia is evident in the Saudis strong preference for managerial positions due to the belief that labor jobs are dishonorable and considered by many to be "a cause of embarrassment" (Idris, 2007). This has significant implications resulting in a "shortage of technical and labor staff" and reliance on foreign labor (Idris, 2007). This may also help to explain why approximately $80 \%$ of the 7.337 million in the labor force are non-nationals (CIA, 2011). 
Saudi Arabia's high power distance also impacts decision making. The ranking indicates that it may be necessary "to go to the top for answers" (Mind Tools, n.d). Generally, "Saudi managers make decisions autocratically and paternalistically" to subordinates who are characterized as having "strong dependence needs" (Bhuian, 1998). During meetings, decision makers are likely to be silent observers and the person doing the significant portion of the talking is likely the least important individual present (Butler, n.d.).

\section{Individualism vs. Collectivism}

The individualism dimension is described as follows:

[i]ndividualism on the one side versus its opposite, collectivism, is the degree to which individuals are integrated into groups. On the individualist side we find societies in which the ties between individuals are loose: everyone is expected to look after her/himself and her/his immediate family. On the collectivist side, we find societies in which people from birth onwards are integrated into strong, cohesive in-groups, often extended families (with uncles, aunts and grandparents) which continue protecting them in exchange for unquestioning loyalty. The word collectivism in this sense has no political meaning: it refers to the group, not to the state. Again, the issue addressed by this dimension is an extremely fundamental one, regarding all societies in the world (Hofstede, n.d.).

Saudi Arabia's individualism ranking of 38 "translates into a Collectivist society as compared to Individualist culture and is manifested in a close long-term commitment to the member 'group', that being a family, extended family, or extended relationships. Loyalty in a collectivist culture is paramount, and over-rides most other societal rules" (Butler, n.d).

Figure 4: Individualism vs. Collectivism - United States vs. Saudi Arabia

\begin{tabular}{|l|l|}
\hline \multicolumn{2}{|c|}{ United States (91) } \\
\hline "I" & "We" \\
\hline Focus on Progress & Focus on Tradition \\
\hline Competitive & Collaborative \\
\hline Individual Achievement & Success and Position Ascribed \\
\hline $\begin{array}{l}\text { "An Enjoyment of Challenges, and an Expectation of Rewards } \\
\text { for Hard Work" }\end{array}$ & "Work for Intrinsic Rewards" \\
\hline "High Valuation on People's Time" & Time is in God's Hands and Delays are the Result of Fate \\
\hline
\end{tabular}

(Butler, n.d.; Roberts \& Taylor, n.d.; Mind Tools, n.d.).

Due to the country's collective nature, relationships generally trump business dealings (Idris, 2007). The notion that an employee's primary obligation is often their family and friends impacts business in several respects. Employment practices such as recruitment and promotions are sometimes influenced by the desire to cater to family and friends versus striving for the best-qualified employee in all situations. Collectivist thinking suggests that payfor-performance systems recognizing individual performance are contrary to the cultural values of group work (Idris, 2007). "In the Arab culture, it is customary to give feedback through an intermediary to avoid conflict and sending the wrong message" (Iqbal, 2010). The effect is that organizations may decide not to assess individual performance and instead opt to "assess the overall organizational outcomes and equally reward all employees, whereas others tend to focus on market factors, e.g., customer satisfaction, relationship building with suppliers and/or customers, and new account openings" (Bhuian, 1998). Islamic beliefs concerning time and delays may have significant impact on planning/scheduling. It may be necessary to delay or reschedule meetings in the event that circumstances triggering collectivist beliefs and thus the need to tend to family or friends occur.

Islamic law prohibits unjust enrichment (Briess, 2009). Interest (riba), which can be "a fixed interest paid on top of any amount loaned, based on the amount of the loan, for a set period of time" is a violation of Islamic teachings (Briess, 2009). The prohibition stems from the "goal of preserving fairness and justness, and avoiding commercial exploitation" and belief that loans with a set rate of return allows the lender to "ignore the borrowing 
party's financial situation, which, aside from injury to the individual also impacts social cohesion" (Briess, 2009). Also, the fact that "Islamic law does not recognize corporations" has implications for recognizing separate legal entities and therefore interest bearing loans between a parent and subsidiary are likely in violation of riba (Briess, 2009).

Both preferred and common stock dividends may be found to be in violation of riba. Due to the fact that cumulative preferred stocks yield a fixed interest payment to the holder "proportionate to the number of shares owned" regardless of company's profits/losses riba is violated. One legal solution is for corporations to reformulate dividends quarterly "within a band (i.e., between $\$ 1.00$ and $\$ 1.20$ ), or re-calculated every quarter using a formula based on various metrics" (Briess, 2009). Other options include using the "dry spell" approach in which the corporation randomly selects one quarter to not pay dividends or basing dividend payments on the year's profits (Briess, 2009). Similarly, bonds with payments based upon the fixed investment are a violation of riba (Briess, 2009).

\section{Masculinity vs. Femininity}

"Masculinity versus its opposite, femininity refers to the distribution of emotional roles between the genders which is another fundamental issue for any society to which a range of solutions are found" (Hofstede, n.d.). Technically, Hofstede was not referring to the roles of sexual orientation but rather the dimension was meant to "reflect the degree to which organizations emphasize competition and assertiveness versus interpersonal sensitivity and concern for relationships" (Schermerhorn, Hunt, \& Osborn, 2004). Saudi Arabia's ranking of 52 compared to the United States ranking of 62 indicates that Saudi Arabia has a more feministic culture (Butler, n.d.).

Figure 5: Masculinity vs. Femininty - United States vs. Saudi Arabia

\begin{tabular}{|l|l|}
\hline \multicolumn{1}{|c|}{ United States (62) } & \multicolumn{1}{|c|}{ Saudi Arabia (52) } \\
\hline Value Opportunity & Value Good Relationship with Supervisors \\
\hline Less Emphasis on Being Caring/Compassionate & Caring/Compassionate \\
\hline Favor Large Scale Enterprises & Favor Small-Scale Enterprises \\
\hline Value Recognition/Advancement & Value Cooperation \\
\hline Value Sense of Accomplishment from Challenging/Rewarding Work & Value Employment Security \\
\hline
\end{tabular}

(Butler, n.d.; Roberts \& Taylor, n.d.)

Saudi Arabia's ranking impacts hiring and firing practices. Research has found that terminations for poor performance rarely happen because the desire for relationships results in life employment (Idris, 2007). This is in stark contrast to at-will employment in the United States. Historically, the society has been characterized as "valu[ing] behavior displaying generosity, selflessness, and hospitality; deference to those above in the hierarchy of the family; freedom from dependence on others and mastery over one's emotions; and a willingness to support other family members and assume responsibility for their errors as well" (LOC, 1992).

\section{Uncertainly Avoidance}

The uncertainty avoidance dimension is described as follows:

[u]ncertainty avoidance deals with a society's tolerance for uncertainty and ambiguity. It indicates to what extent a culture programs its members to feel either uncomfortable or comfortable in unstructured situations. Unstructured situations are novel, unknown, surprising, different from usual. Uncertainty avoiding cultures try to minimize the possibility of such situations by strict laws and rules, safety and security measures, and on the philosophical and religious level by a belief in absolute Truth: "there can only be one Truth and we have it". People in uncertainty avoiding countries are also more emotional, and motivated by inner nervous energy. The opposite type, uncertainty accepting cultures, are more tolerant of opinions different from what they are used to; they try to have as few rules as possible, and on the philosophical and religious level they are relativist and allow many currents to flow side by 
side. People within these cultures are more phlegmatic and contemplative, and not expected by their environment to express emotions (Hofstede, n.d.).

Saudi Arabia's uncertainty avoidance ranking of 68 “indicates the society's low level of tolerance for uncertainty. In an effort to minimize or reduce this level of uncertainty, strict rules, laws, policies, and regulations are adopted and implemented. The ultimate goal of these populations is to control everything in order to eliminate or avoid the unexpected. As a result of this high Uncertainty Avoidance characteristic, the society does not readily accept change and is very risk adverse" (Butler, n.d.).

Figure 6: Uncertainty Avoidance - United States vs. Saudi Arabia

\begin{tabular}{|l|l|}
\hline \multicolumn{1}{|c|}{ United States (46) } & \multicolumn{1}{|c|}{ Saudi Arabia (68) } \\
\hline Risk Inclined & Risk Averse \\
\hline "Informal business attitude" & "Very formal business conduct with lots of rules and policies" \\
\hline $\begin{array}{l}\text { "More concern with long term strategy than what is happening } \\
\text { on a daily basis" }\end{array}$ & "Need and expect structure" \\
\hline Acceptance of Change & Fear of Change \\
\hline Value Differences & "Differences are avoided" \\
\hline
\end{tabular}

(Butler, n.d.; Roberts \& Taylor, n.d.; Mind Tools, n.d.).

Saudi Arabia's ranking suggests that "[n]ew projects will be carefully analyzed to assure that whatever risk they represent is thoroughly understood and addressed. In order for change to take hold, the idea needs to be perceived as good for the group and be accepted by the group" (Kwintessential, n.d.). Due to Saudi Arabia's uncertainty avoidance ranking, there is a notion that Saudis prefer government intervention in business practices. Within organizations, the ranking is evident in the fact that Saudi managers are generally not tolerant of deviation of the generally rigid company rules (Bhuian, 1998). This formality effects the environment and productivity within organizations. This dimension may also help to explain the country's slow road to privatization.

\section{Long-Term Orientation}

Long term-orientation (LTO) is the fifth dimension of Hofstede's model. LTO

focuses on the degree the society embraces, or does not embrace, long-term devotion to traditional, forward thinking values. High Long-Term Orientation ranking indicates the country prescribes to the values of long-term commitments and respect for tradition. This is thought to support a strong work ethic where long-term rewards are expected as a result of today's hard work. However, business may take longer to develop in this society, particularly for an "outsider". A Low Long-Term Orientation ranking indicates the country does not reinforce the concept of long-term, traditional orientation. In this culture, change can occur more rapidly as long-term traditions and commitments do not become impediments to change. (International Business Center, n.d.).

The third edition of Cultures and Organizations: Software of the Mind provides the following helpful chart to illustrate differences between countries with short or long-term orientation. 
Figure 7: Characteristics of Short-Term Orientation Versus Long-Term Orientation

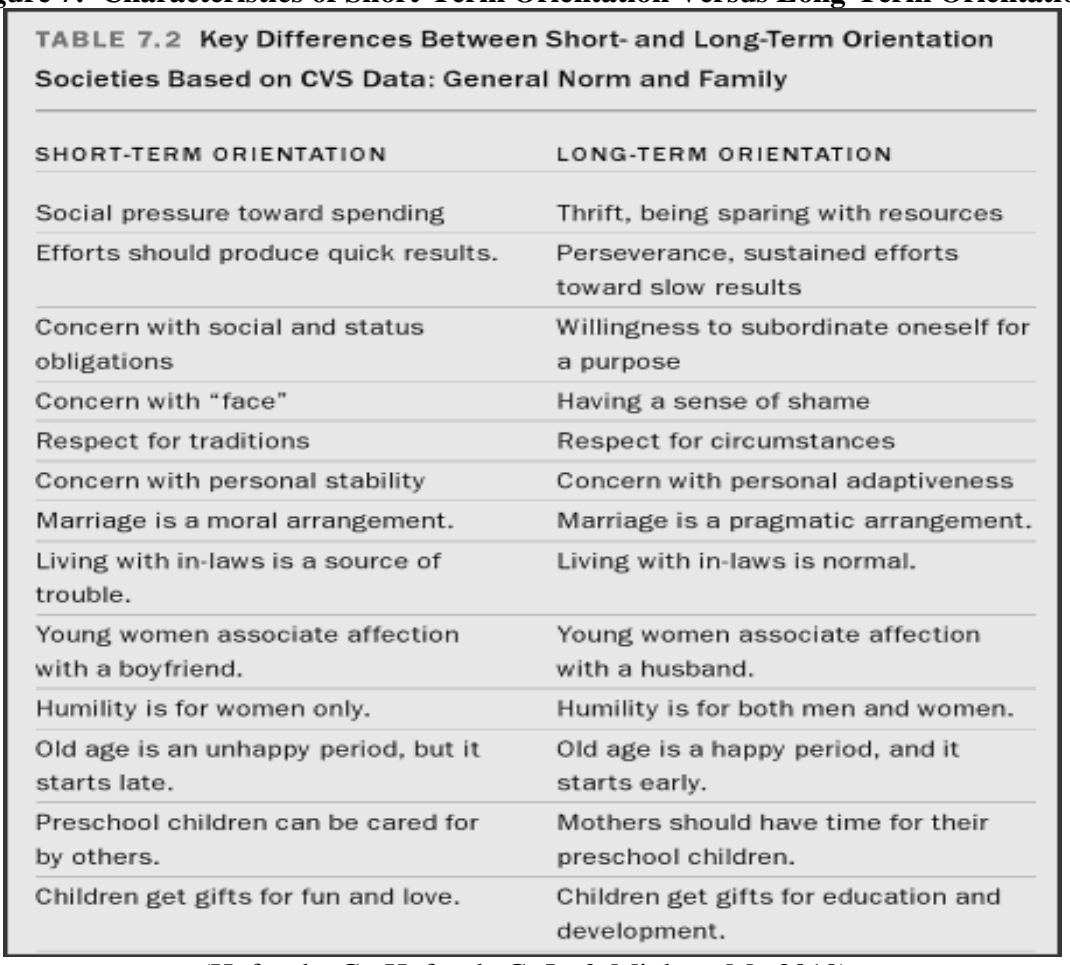

(Hofstede, G., Hofstede G. J., \& Minkov, M., 2010).

The LTO dimension was not part of Hofstede's initial groundbreaking study. The LTO dimension originates from

[r]esearch by Michael Bond and colleagues among students in 23 countries [in 1991 which led] to adding a fifth dimension called Long-versus Short-Term Orientation. In 2010, research by Michael Minkov allowed to extend the number of country scores for this dimension to 93, using recent World Values Survey data from representative samples of national populations. Long-term oriented societies foster pragmatic virtues oriented towards future rewards, in particular saving, persistence, and adapting to changing circumstances. Short-term oriented societies foster virtues related to the past and present such as national pride, respect for tradition, preservation of "face", and fulfilling social obligations (Hofstede, n.d.).

The United States was among the original 23 countries to receive a LTO score based upon the Chinese Values Survey. See (Hofstede \& Minkov, 2010) for a more detailed discussion. "The LTO is the lowest Dimension for the US at 29, compared to the world average of 45. This low LTO ranking is indicative of the societies' belief in meeting its obligations and tends to reflect an appreciation for cultural traditions" (Itim International, n.d.). The ranking also "reflects a freedom in the culture from long-term traditional commitments, which allows greater flexibility and the freedom to react quickly to new opportunities" (Roberts \& Taylor, n.d.).

Saudi Arabia was not among the 23 countries originally analyzed. However, recent articles provide insights into Saudi Arabia's ranking with respect to the long-term orientation dimension. The article "Long-Versus Short-Term Orientation: New Perspectives" reports scores of 26 for the United States and 36 for Saudi Arabia based upon the World Values Survey (Hofstede \& Minkov, 2010). In the article "Hofstede's Fifth Dimension: New Evidence from the World Values Survey" Minkov \& Hofstede "attempted to replicate [the LTO] dimension by analyzing World Values Survey (WVS) items that seemed to capture the concept of LTO" (Minkov \& Hofstede, 2010). The resulting Long-Term Orientation Index reported scores of 39 and 37 for the United States and Saudi Arabia respectively. (Minkov \& Hofstede, 2010). 
It appears that the United States and Saudi Arabia do not vary greatly in their scores for the long-term orientation dimension. This, however, does not mean that there are not significant differences in the business context between the countries due to the long-term orientation dimension and the interplay of the other dimensions. When scheduling meetings with Saudi Arabian counterparts it is important to respect religious traditions and schedule in "accordance with the five daily prayer times and religious holidays of Ramadan and Hajj" (Gorrill, 2007). On the day of the meeting, it is not unusual for Saudi Arabians to be "unpunctual compared to Western standards" due to other obligations. (Gorrill, 2007). During meetings, it is important to be cognizant that preventing the loss of face is important in Saudi Arabia and therefore pressure, confrontation, and conflict should be avoided. In contrast to the competitive nature often found in the United States to seal the deal at all costs, "[d]ignity and respect are key elements in Saudi Arabian culture and saving face, through the use of compromise, patience and self-control is a means by which to maintain these qualities" (Gorrill, 2007). This translates into the desire for faceto-face meetings and slower negotiations to build relationships with trust. It is important to remember that "Saudis will not want to upset others in order to force adherence to a deadline. Things generally take longer than expected since meetings are frequently interrupted and several meetings may be required" (Kwintessential, n.d.).

\section{CONCLUSION}

Culture undeniably influences business and legal environments. This paper highlighted cultural differences that may manifest while conducting business in Saudi Arabia. Dr. Hofstede has recognized that the

dimensions do not directly predict any phenomena or dynamics. Applying them to make sense of what happens in the world always has to take into account other factors as well as culture - notably national wealth, history, personalities, and coincidences. There is no quick fix to understand social life after taking a dose of Hofstede. But the dimensions, when well understood, do allow to predict a little better what is likely to happen. And they become more useful as you go from the specific case to the trend, average, or expectation (Hofstede, n.d.).

This research identified various aspects of the business and legal environment in Saudi Arabia that are consistent with Hofstede's rankings. This suggests that Hofestede's Model remains a valuable tool to begin to understand and appreciate a given culture.

\section{AUTHOR INFORMATION}

Macgorine A. Cassell earned his Ph.D. from United States (Alliant) International University. He is a Professor of Business Administration at Fairmont State University in Fairmont, West Virginia. His research and publications are in the areas of diversity in the workplace, intercultural communication, workplace violence, outsourcing, leadership practices and effectiveness. E-mail: mcassell@fairmontstate.edu. Corresponding author.

Rebecca J. Blake is a J.D. Candidate at West Virginia University College of Law.

\section{REFERENCES}

1. Bhuian, S. (1998). "An empirical examination of market orientation in Saudi Arabian manufacturing companies." Journal of Business Research, 43, 13-25.

2. Briess, C. (Fall 2009). "The crescent and the corporation: Analysis and resolution of conflicting positions between the western corporation and the Islamic legal system." Richmond Journal of Global Law and Business, 453-511.

3. Butler, P. (n.d.) Saudi Arabia. Retrieved from http://www.cyborlink.com/besite/saudi-arabia.htm.

4. Central Intelligence Agency. (2011). The world factbook. Middle East: Saudi Arabia. Retrieved from https://www.cia.gov/library/publications/the-world-factbook/geos/sa.html.

5. Fakkar, G. (2010, March 8). Decision to set up commercial courts receives wide welcome. Retrieved from http://arabnews.com/saudiarabia/article27201.ece.

6. Gorrill, J. (2007). Doing business in Saudi Arabia: Saudi Arabian social and business culture. Retrieved from http://www.communicaid.com/cross-cultural-training/culture-for-business-and-management/doingbusiness-in/Saudi-arabian-business-and-social-culture.php. 
7. Hofstede, G. (n.d.). Research and VSM. Retrieved from http://www.geerthofstede.nl/research--vsm.aspx.

8. Hofstede, G., Hofstede G. J., and Minkov, M. (2010). Cultures and Organizations: Software of the Mind, $3^{\text {rd }}$ Ed., McGraw-Hill.

9. Hofstede, G. and Minkov, M. (2010, October). Long-versus short-term orientation: new perspectives. Asia Pacific Business Review, 16(4), 493-504.

10. Idris, A. (2007). Cultural barriers to improved organizational performance in Saudi Arabia. SAM Advanced Management Journal , 72 (2), 36-54.

11. Iqbal, A. (Dec. 2010). Employee turnover: Causes, consequences and retention strategies in Saudi organizations. The Business Review, Cambridge, 16.2, 275-281.

12. Kwintessential. (n.d). Intercultural management: Saudi Arabia. Retrieved from http://www.kwintessential.co.uk/intercultural/management/saudiarabia.html.

13. Kwong, K. \& Levitt, C. (2009). "The impact of national culture on value based decisions: Comparison of Saudi Arabian, Egyptian, and American healthcare professionals." Academy of Health Care Management Journal, 5.1-2., 79-97.

14. Mind Tools. (n.d). Hofstede's cultural dimensions: Understanding workplace values around the world. Retrieved from http://www.mindtools.com/pages/article/newLDR 66.htm.

15. Minkov, M. and Hofstede, G. (2010, Dec. 15). Hofstede's Fifth Dimension: New evidence from the World Values Survey. Available at http://jcc.sagepub.com/content/early/2010/12/14/0022022110388567.

16. Myers, L. (Spring/Summer 2007). The Clarke Program in East Asian law and culture: Exciting conversations on law and culture. In Cornell Law Forum, Vol. 33, No. 3.

17. Itim International. (n.d.). Geert Hofstede cultural dimensions. Retrieved from http://www.geerthofstede.com/index.shtml.

18. Rice, Gillian. (Jan/Feb 2004). "Doing business in Saudi Arabia." Thunderbird International Business Review.

19. Roberts, K. and Taylor S. (n.d.). United States of America. Retrieved from http://www.cyborlink.com/besite/us.htm.

20. Schermerhorn, J., Hunt, J., and Osborn, R. (2004). Core Concepts of Organizational Behavior. US: John Wiley \& Sons.

21. The International Bank for Reconstruction and Development \& The World Bank. (2011a). Doing business 2011 report: Economy rankings. Retrieved from http://www.doingbusiness.org/rankings.

22. The International Bank for Reconstruction and Development \& The World Bank. (2011b). Doing business 2011 report: Business reforms in Saudi Arabia. Retrieved from http://www.doingbusiness.org/reforms/overview/economy/saudi-arabia.

23. The International Bank for Reconstruction and Development \& The World Bank. (2011c). Doing business 2011 report: Ease of doing business in Saudi Arabia. Retrieved from http://www.doingbusiness.org/data/exploreeconomies/saudi-arabia/.

24. The Library of Congress. (1992). A country study: Saudi Arabia. Retrieved from http://memory.loc.gov/frd/cs/satoc.html.

25. U.S. Department of State. (2010). Background note: Saudi Arabia. Retrieved from http://www.state.gov/r/pa/ei/bgn/3584.htm. 
International Journal of Management \& Information Systems - Second Quarter $2012 \quad$ Volume 16, Number 2

NOTES 